$\underline{\text { Review article }}$

\title{
Second-Generation Tyrosine Kinase Inhibitors (Tki) as Salvage Therapy for Resistant or Intolerant Patients to Prior TKIs
}

Massimo Breccia and Giuliana Alimena

Department of Cellular Biotechnologies and Hematology, Sapienza University, Rome, Italy

Correspondence to: Giuliana Alimena, MD. Department of Cellular Biotechnologies and Hematology, the Sapienza University of Rome, Via Benevento 6, 00161 Roma, Italy. Tel. 00390685795305, Fax 00390644241984. EMAILmail: alimena@bce.uniroma1.it

Competing interests: The authors have declared that no competing interests exist.

Published: January 2, 2014

Received: Accepted November 26, 2013

Accepted: November 11, 2013

Citation: Mediterr J Hematol Infect Dis 2014, 6(1): e2014003, DOI: 10.4084/MJHID.2014.003

This article is available from: http://www.mjhid.org/article/view/12456

This is an Open Access article distributed under the terms of the Creative Commons Attribution License (http://creativecommons.org/licenses/by/2.0), which permits unrestricted use, distribution, and reproduction in any medium, provided the original work is properly cited.

Abstract. With the advent of target therapies, imatinib became the mainstay for treatment of chronic myeloid leukemia. However, despite the brilliant results obtained with this drug, more than $30 \%$ of patients discontinue therapy in long-term due to several reasons, including failure and/or intolerance. Second-generation tyrosine kinase inhibitors (TKIs) are more potent drugs and have expanded inhibition against a broad spectrum of mutations resistant to imatinib. Both nilotinib and dasatinib have demonstrated in vitro and in vivo clinical activity against different types of mutations and various forms of resistance. However, patients with T315I mutation do not obtain an advantage from these drugs and a third generation inhibitor ponatinib, a pan-BCR drug, was tested with significant results. In this review, we report the results of second- and third-generation TKIs tested as second or third line therapy in patients resistant and/or intolerant to previous inhibitors.

Introduction. Although the use of standard dose imatinib as first therapeutic strategy has dramatically changed the outcome of chronic myeloid leukemia patients in chronic phase, one third of patients does not achieve an optimal outcome and requires alternative therapies due to the emergence of drug resistance. Eight-year follow-up of the international IRIS study showed $85 \%$ overall survival (OS) rate, but $30 \%$ of patients had unfavourable outcome, mostly due to primary $(17 \%)$ or acquired resistance $(15 \%){ }^{1}$

In 2006, the European LeukemiaNet (ELN) group published recommendations and identified at 3, 6, 12 and 18 months different categories of patients defined as optimal or suboptimal response or failure to imatinib given as first line therapy. ${ }^{2}$ In 2013 the recommendations were updated ${ }^{3}$ and the category of suboptimal patients was excluded while resistant patients were identified also based on early evaluation of molecular response. Resistance mechanisms were studied first in vitro and then in vivo, and allowed the development of second-generation tyrosine kinase inhibitors. These agents were tested on a large series of patients resistant and/or intolerant to imatinib, providing the basis for prescription in second line.

In the present paper, we analyse the different options for patients resistant or intolerant to TKIs 
through a review of second-generation drugs trials performed in this category of subjects.

Dasatinib. Dasatinib is a second-generation BCR-ABL inhibitor that has 325 -fold higher potency in vivo with inhibitory activity against the majority of imatinibresistant BCR-ABL mutants. Several studies tested the efficacy and safety of dasatinib as a second line therapy ${ }^{4}$. Phase II START-C trial ${ }^{5}$ evaluated dasatinib as a single agent at the dose of $70 \mathrm{mg}$ twice daily in 387 patients with resistance $(75 \%)$ or intolerance $(25 \%)$ to imatinib. Fifty-five percent of patients had received as prior therapy high doses of imatinib, and $10 \%$ of patients were included after failure of bone marrow transplantation. Complete hematologic remission (CHR) was achieved by $90 \%$ of patients; major cytogenetic response (MCyR) was obtained in $62 \%$ of patients with $88 \%$ of these maintaining the response at 24 months. Complete cytogenetic response (CCyR) rate was 53\%, and this response was maintained in $90 \%$ of patients at 24 months. PFS at 2 years was $80 \%$, and 2-year OS was $94 \%$. Mutations of the kinase domain were detected at baseline in $44 \%$ of enrolled patients, with high frequency of G250E and T315I mutations. The presence of mutations at baseline, even if detected in the p-loop region, did not influence overall response rate. ${ }^{5}$ A subsequent subanalysis was reported by Branford and colleagues on the development of new detectable mutations in 479 patients treated with dasatinib after imatinib failure: the results showed that the emergence of new mutations, such as T315A, F317L, V299L, occurred in only 13\% of treated patients. ${ }^{6}$ As regards hematological adverse events of grade $3 / 4$ reported in the first 2 years, these consisted predominantly of neutropenia $(50 \%)$ and thrombocytopenia (49\%). Non-hematological adverse events observed in this trial consisted prevalently of diarrhea, headache, rash and fatigue, but were of grade $3 / 4$ in $<5 \%$ of patients with a slight increase in the prevalence between the first and the second year of follow-up. Pleural effusion rate was $22 \%$, but the majority of cases were grade $1 / 2$ (grade 3 in less than $10 \%$, with no grade 4) and most occurred during the first two years, of follow-up 7 . Cross-intolerance between imatinib and dasatinib was not evidenced in this trial. ${ }^{5,7}$

The START-R trial included imatinib-resistant patients that were randomized, with a ratio of $2: 1$, to dasatinib $70 \mathrm{mg}$ twice daily or high-dose imatinib (800 mg daily). ${ }^{8}$ After 2-year follow-up, CHR was obtained in $93 \%$ of patients treated with dasatinib and in $82 \%$ of patients treated with high-dose imatinib. A higher MCyR rate was observed among patients treated in the dasatinib arm than in the imatinib arm $(53 \%$ vs. $33 \%$; $\mathrm{p}=0.017$ ), with a CCyR rate of $44 \%$ and $18 \%$, respectively. MCyR was maintained in $90 \%$ of patients in the dasatinib arm and in $74 \%$ of patients in the highdose imatinib arm. Major molecular responses (MMR) were also more frequently seen in patients treated with dasatinib than in those treated with highdose imatinib (29\% vs. $12 \%)$. As in other trials, the most frequent grade $3 / 4$ events with dasatinib was neutropenia, thrombocytopenia and leukopenia, diarrhea, fatigue and headache. ${ }^{8}$ START-R study results showed that second-generation drug represents a better choice for resistant patients compared with dose escalation of imatinib.

START-A trial recruited 174 accelerated phase (AP) CML patients, with the majority of them being resistant to imatinib. At a minimum follow-up of 14 months, major hematologic response (MaHR) and CHR were achieved in $64 \%$ and $45 \%$ of patients treated with dasatinib $70 \mathrm{mg}$ twice daily. MCyR and CCyR were obtained in $39 \%$ and $32 \%$ of patients, respectively. No significant differences in terms of rate of responses were observed among resistant or intolerant patients, previous stem cell transplant or presence of baseline mutations. At a median follow-up of 1 year, PFS and OS were $66 \%$ and $82 \%$. Grade $3 / 4$ neutropenia and thrombocytopenia occurred in $76 \%$ and $82 \%$ of patients, respectively. Diarrhoea occurred in $52 \%$ of patients with $8 \%$ being of grade $3 / 4$, whereas pleural effusion occurred in $27 \%$ of patients $(5 \%$ as grade $3 / 4){ }^{9}$

Dasatinib was tested also in CML blast phase (BP) and $\mathrm{Ph}+$ acute lymphoblastic leukemia (ALL) (START-B and START-L trials); the former enrolled 74 myeloid blast phase (MBP) and 42 lymphoid blast phase (LBP) patients. ${ }^{10}$ At 8-month follow-up the rates of MaHR were $34 \%$ and $31 \%$ in MBP and LBP, respectively; MCyR rates were $31 \%$ and $50 \%$, while CCyR rates were $27 \%$ and $43 \%$, respectively. More resistant mutations (M244V, G250E, Y253H, E255K, E255V, T315I, F359V, H396R) were associated with lower response rates to dasatinib. Among MBP patients, the most frequently encountered AEs were diarrhoea $(36 \%)$, pleural effusion $(28 \%, 14 \%$ as grade $3 / 4)$, peripheral oedema (19\%), and dyspnoea (18\%). Common side effects observed in LBP patients were diarrhoea (31\%), fatigue (29\%), nausea and vomiting (24\%). The START-L trial reported the results obtained in $36 \mathrm{Ph}+$ acute lymphoblastic leukemia (ALL). ${ }^{11}$ Out of 24 patients (67\%) who had achieved a MaHR, 5 experienced disease progression and CCyR rate at 8-month follow-up was 58\%. No differences in response rates were revealed for patients with resistant mutations compared to whole non-mutated population: T315I mutation was found at baseline in 6 patients and was associated with a worse response. The most frequently reported AEs of any grade in ALL were 
diarrhoea (31\%), pyrexia (25\%), and nausea (22\%), whereas the most common grade $3 / 4$ events, were febrile neutropenia (11\%), diarrhoea (8\%), and asthenia (8\%). The results of trials in an advanced phase of disease showed that dasatinib is a valid option due to its large spectrum of inhibition, even if in most of the patients treated in blast crisis the responses were not long lasting.

CA180-034 study was an international, open-label, four-arm randomized phase III study, which enrolled 662 patients resistant or intolerant to prior imatinib therapy. Patients received $140 \mathrm{mg}$ or $100 \mathrm{mg}$ of dasatinib, both administered in one (QD) or two daily (BID) doses. ${ }^{12}$ Baseline features, as well as outcomes at 72 months, were similar among the different arms. ${ }^{13}$ CHR was achieved in $92 \%$ of the $100 \mathrm{mg}$ QD arm, in $88 \%$ of the $70 \mathrm{mg}$ BID arm, in $87 \%$ of the $140 \mathrm{mg}$ QD arm and in $92 \%$ of the $50 \mathrm{mg}$ BID arm. CCyR was achieved in $50 \%$ and $53 \%$ of the $100 \mathrm{mg}$ QD and 70 mg BID arms, respectively, and in $50 \%$ and $49 \%$ of the $140 \mathrm{mg}$ QD and $50 \mathrm{mg}$ BID cohorts, respectively. MMR rate was $45 \%$ in the $100 \mathrm{mg}$ QD cohort at the last follow-up of 72 months. OS was estimated to be $71 \%$ in the $100 \mathrm{mg}$ QD arm with a cumulative incidence of death due to CML of $12.5 \%$. PFS in the $100 \mathrm{mg}$ QD arm was estimated to be $49 \%$ at 6 years. A comprehensive sub-analysis, including patients treated in phase II/III trials because resistant to imatinib, showed that the drug was active against several ABL mutations. The results showed that the drug induced high cytogenetic and molecular response rates in imatinib-resistant patients with and without mutations at baseline (including mutations at residues G250, M351, L248, Y253, E255, F359 and H396). However, mutations with half maximal inhibitory concentration $\left(\mathrm{IC}_{50}\right)>3 \mathrm{nM}$ obtained a CCyR rate of $32 \%$ and MMR rate of $23 \%$ compared to CCyR rate of $53 \%$ and MMR of $38 \%$ of patients with $\mathrm{IC}_{50}<3 \mathrm{nM}$, with also different PFS, that was $67 \%$ in $\mathrm{IC}_{50}>3 \mathrm{nM}$ group and $80 \%$ in $\mathrm{IC}_{50}<3$ nM group. ${ }^{14}$

A subsequent phase 3 study assessed safety and efficacy of two different schedules (140 mg QD or 70 mg BID) of dasatinib in patients in blast phase. A twoyear follow-up showed that MaHRs were similar in MBP treated with the two different schedules (28\%), whereas for LBP the response rate was $42 \%$ for 140 $\mathrm{mg}$ QD and $32 \%$ for $70 \mathrm{mg}$ BID. MCyR rate was $25 \%$ for $140 \mathrm{mg}$ QD and $28 \%$ for $70 \mathrm{mg}$ BID in MBP patients and respective rates were $50 \%$ and $40 \%$ for LBP. Two-year OS rate with $140 \mathrm{mg}$ QD and with 70 $\mathrm{mg}$ BID was $24 \%$ and $28 \%$ in MBP patients, respectively and $21 \%$ and $16 \%$ in LBP, respectively. In this trial a trend of better tolerability was reported among patients treated with $140 \mathrm{mg}$ QD. ${ }^{15}$
Nilotinib. Nilotinib (Tasigna) was rationally designed to have enhanced selectivity and potency toward BCR$\mathrm{ABL}$, with clinical activity against the majority of resistant mutations to imatinib and was recommended as second line therapy for $\mathrm{CP}$ and $\mathrm{AP}$ patients resistant or intolerant to a previous imatinib. ${ }^{16}$

Nilotinib was tested in a phase II trial enrolling 321 $\mathrm{CP}$ patients with resistance or intolerance to imatinib that received nilotinib at 400 BID. Results were reported at a median follow-up of 48 months: $94 \%$ of patients reached CHR in a median time of 1 month and $59 \%$ of patients achieved MCyR in a median time of 1.4 months, with $45 \%$ of these being CCyR; $78 \%$ of patients achieving MCyR, maintained this response. MMR rate was $28 \%$, PFS was $57 \%$ and OS was $78 \% .^{17}$ Grade 3/4 neutropenia and thrombocytopenia occurred in $30 \%$ of patients; the most frequent non haematological side effects reported were biochemical abnormalities, including an increase of lipase/amylase, total bilirubin and hyperglycemia; other nonhematologic side effects included skin rash, nausea and headache. A mutational screening at baseline revealed that 114 out of 281 tested patients $(41 \%)$ presented a mutation. The results of this sub-analysis showed that mutations with IC50 > $150 \mathrm{nM}$ occurred in $14 \%$ of resistant patients and affected prevalently 3 amino acid residues (Y253H, E255K/V, F359C/V); 15\% of patients had a mutation with unknown IC50. After 12 months of therapy, MCyR rates of mutated patients (both with IC50 $<150 \mathrm{nM}$ and with unknown IC50) were comparable to those of non-mutated patients (MCyR 49\% vs 60\%, respectively). MCyR in mutated patients with IC50 > $150 \mathrm{nM}$ was less favourable $(19 \%)$. Disease progression rate was higher in mutated patients when compared to that of patients without mutations ( $46 \%$ vs $26 \%$ ); in patients with IC50 > 150 $\mathrm{nM}$ the rate was $69 \% .^{18}$

An expanded access characterized safety of nilotinib in a large series of patients $(1,422)$. In CP subjects, the CHR and CCyR rates were $43 \%$ and $34 \%$, respectively. Faster responses were detected in particular in patients with sub-optimal response to imatinib, who reached $50 \%$ of CCyR. The 18-month PFS was $80 \%$. Non-hematologic side effects reported were mild to moderate and included rash, headache, nausea and elevations in serum bilirubin and lipase that occurred in 45 and $7 \%$ of patients, respectively. ${ }^{19}$ In the same series of patients, 181 were in accelerated phase and 190 in blast phase (133 myeloid, 50 lymphoid and 7 unknown). As regards toxicity, myelosuppression was usually manageable with drug dose reductions or temporary interruptions, and grade $3 / 4$ increase in serum bilirubin and lipase were infrequent. ${ }^{20}$

Nilotinib at the dose of $400 \mathrm{mg}$ BID was tested in 105 MBP patients and 31 LBP: at 2-year follow-up, 
$60 \%$ of MBP and 59\% of LBP had achieved a MaHR and $38 \%$ and $52 \%$ had obtained an MCyR, respectively. CCyR rate was $30 \%$ and $32 \%$, respectively. Two-year OS was $32 \%$ for MBP and $10 \%$ for LBP patients. Fourteen patients underwent allogeneic stem cell transplant. Hematological toxicity was frequent with grade $3 / 4$ neutropenia, thrombocytopenia and anemia occurring in $68 \%, 63 \%$ and $47 \%$, respectively. Laboratory abnormalities were common, with grade $3 / 4$ hypophosphatemia being detected in $15 \%$, hyperbilirubinemia in $11 \%$ and lipase elevation in $11 \%$ of patients. ${ }^{21}$

Bosutinib. Bosutinib (or SKI-606) is an oral oncedaily dual Src/ABL inhibitor approved by FDA for the treatment of adult patients with $\mathrm{CP}$, AP or $\mathrm{BP}$ $\mathrm{Ph}+\mathrm{CML}$, resistant or intolerant to imatinib or secondgeneration TKIs. It was tested in a phase I/II study, which enrolled 288 patients (200 resistant and 88 intolerant to imatinib) and the final dose of $500 \mathrm{mg}$ QD was found. After a median follow-up of 24 months, $86 \%$ of patients achieved a CHR, 53\% an MCyR (of them $41 \%$ had a CCyR). Among patients with CCyR, $64 \%$ of imatinib-resistant and 65\% of imatinibintolerant patients achieved MMR with CMR being obtained in $49 \%$ of imatinib-resistant and $61 \%$ of imatinib-intolerant patients. Two-year OS was $92 \%$. Responses were seen across all types of mutants, with the exception of T315I. Most frequent side effects reported were diarrhea, rash and vomiting. ${ }^{22}$

Bosutinib was tested also in third line after imatinib and dasatinib and/or nilotinib failure (37 patients resistant and 50 intolerant to dasatinib; 27 patients resistant and 1 intolerant to nilotinib). The study included 118 patients that, after a median follow-up of 28 months, achieved CHR with a rate of $73 \%$ and CCyR with a rate of $24 \%$. An MCyR was reported for $31 \%$ and $30 \%$ of dasatinib resistant and intolerant patients, with $14 \%$ and $28 \%$ achieving a CCyR, respectively. An MCyR and CCyR were observed in $35 \%$ and $27 \%$ of patients resistant to nilotinib. After 2 years, PFS was $73 \%$ with a median OS estimated to be $83 \%$. Also in third line, bosutinib was able to overcome all types of mutations (including mutations resistant to dasatinib and nilotinib, with the most frequent being F317L, T351I, G250E and Y253H), except T315I. ${ }^{23}$

A recent sub-analysis of 119 patients aged over 65 years treated with bosutinib was reported in comparison with 451 younger patients. ${ }^{24}$ Bosutinib was administered at the dose of $500 \mathrm{mg} /$ day in 3 cohorts consisting of $\mathrm{CP}$ patients after imatinib failure, CP patients after imatinib and dasatinib or nilotinib failure and patients in advanced phases of disease. Bosutinib was discontinued in $80 \%$ of patients aged over 65 years compared to $67 \%$ of younger patients, in $32 \%$ of cases owing to adverse events, mostly thrombocytopenia. Similar response rates were obtained in older patients in terms of CHR in the first two cohorts of patients $(81 \%$ and $72 \%)$ and in terms of CCyR (38\% and 23\%). Rate of disease transformation was similar between older and younger patients. Two-year OS was $87 \%$ and $80 \%$ respectively in the two categories of patients, whereas 2-year PFS was $76 \%$ and $70 \%$. Incidence of haematological side effects as well as of diarrhea was similar between older and younger patients.

Bosutinib was evaluated also in 63 patients with $\mathrm{AP}$, in 48 with $\mathrm{BP}$ and in 23 with Ph+ALL. After a median follow-up of 8 months, $61 \%$ of AP patients and $32 \%$ of BP achieved a CHR. MCyR and CCyR rates were $48 \%$ and $33 \%$ in AP patients and $52 \%$ and $29 \%$ in BP patients, respectively. MMR and CMR rates were $15 \%$ and $4 \%$ in AP patients and $28 \%$ and $12 \%$ in BP patients, respectively. Also in advanced phase of disease, bosutinib was found to be active in mutated patients. $^{25}$

Ponatinib. A third generation inhibitor was recently tested in resistant/intolerant CML patients: ponatinib is a potent, synthetic, oral multi-target pan-BCR/ABL inhibitor able to block native and mutated BCR/ABL, including T315I mutation, resistant to dasatinib and nilotinib. The results of a phase 1 dose-escalation study, which enrolled 81 patients (60 with CML), showed dose-limiting side effects, which included elevated lipase and amylase and pancreatitis. Of 43 chronic phase CML patients, $72 \%$ achieved an MCyR and $44 \%$ a MMR. Similar responses were obtained in patients without mutations and with $\mathrm{T} 315 \mathrm{I}{ }^{26}$ The PACE trial (Ponatinib Ph+ ALL and CML Evaluation), a phase 2 open-label trial, tested ponatinib $45 \mathrm{mg}$ QD in 449 patients resistant or intolerant to dasatinib or nilotinib or with T315I mutation in different phases of the disease. Of the 444 patients included in the efficacy analysis, 267 were in CP, 83 in AP, 62 in MBP and 32 had $\mathrm{Ph}+\mathrm{ALL}$. A total of 128 patients were positive for T315I mutation. Primary endpoint was the achievement of MCyR. Overall rate of MCyR in CP patients was $54 \%$ with $44 \%$ of CCyR. Among these patients, 64 had a T315I mutation and 70\% achieved an MCyR with $66 \%$ of CCyR. In AP and BP patients MaHR was evaluated as primary endpoint: overall, in AP patients the rate was $52 \%$ and of these $44 \%$ were CHR $(39 \%$ in T315I mutated patients), whereas, in BP patients, the rate was $31 \%(29 \%$ in T315I patients). Safety evaluation revealed that the most common adverse events were hypertension, rash, abdominal pain, fatigue, headache, arterial thrombosis and hepatotoxicity. In particular $11 \%$ of patients experienced arterial thrombosis that was serious in $8 \%$ of instances. Congestive heart failure was recorded in 
Table 1. Summary of responses in chronic phase CML patients treated with second or third generation TKI.

\begin{tabular}{|c|c|c|c|c|c|c|c|}
\hline TKI & Studies & No. patients/treatment & CHR & CCyR & MMR & OS & PFS \\
\hline \multirow{7}{*}{ Dasatinib } & START-C* & 387 (dasatinib 70 mg BID) & $90 \%$ & $53 \%$ & - & $94 \%$ & $80 \%$ \\
\hline & START-R** & 101 (dasatinib 70 mg BID) & $93 \%$ & $44 \%$ & $29 \%$ & $\mathrm{nr}$ & $86 \%$ \\
\hline & START-R & 49 (high-dose imatinib $800 \mathrm{mg}$ ) & $82 \%$ & $18 \%$ & $12 \%$ & $\mathrm{nr}$ & $65 \%$ \\
\hline & CA180-034*** & 167 (dasatinib 100 mg QD) & $92 \%$ & $50 \%$ & $42 \% * * *$ & $71 \% * * *$ & $49 \% * * *$ \\
\hline & & 168 (dasatinib 70 mg BID) & $88 \%$ & $53 \%$ & $43 \%$ & $70 \% * * *$ & $47 \% * * *$ \\
\hline & & 167 (dasatinib $140 \mathrm{mg}$ QD) & $87 \%$ & $50 \%$ & $42 \%$ & $77 \% * * *$ & $40 \% * * *$ \\
\hline & & 168 (dasatinib 50 MG BID) & $92 \%$ & $49 \%$ & $41 \%$ & $74 \% * * *$ & $51 \% * * *$ \\
\hline \multirow{3}{*}{$\begin{array}{l}\text { Nilotinib } \\
\text { Bosutinib } \\
\text { Ponatinib }\end{array}$} & $0321 * * * *$ & 321 (nilotinib 400 mg BID) & $94 \%$ & $45 \%$ & $28 \%$ & $78 \%$ & $57 \%$ \\
\hline & Phase I/II** & 288 (bosutinib 500 mg QD) & $86 \%$ & $41 \%$ & $64 \%$ & $92 \%$ & $\mathrm{nr}$ \\
\hline & PACE & 267 (ponatinib $45 \mathrm{mg}$ QD) & $\mathrm{nr}$ & $46 \%$ & $34 \%$ & $94 \%$ & $80 \%$ \\
\hline
\end{tabular}

$\mathrm{QD}=$ once daily; $\mathrm{BID}=$ twice daily, at 2-year follow-up, $\mathrm{CHR}=$ complete hematological remission, $* *$ at 2-year follow-up, CCR= complete cytogenetic remission, $* * *$ at 6 -year follow-up, MMR = major molecular response, $* * * *$ at 4 -year follow-up, OS= overall survival, $\mathrm{PFS}=$ progression-free survival.

Table 2. Targets inhibited by imatinib, nilotinib, dasatinib, bosutinib, ponatinib

\begin{tabular}{|c|c|c|c|c|}
\hline IMATINIB & NILOTINIB & DASATINIB & BOSUTINIB & PONATINIB \\
\hline $\mathrm{ABL}$ & $\mathrm{ABL}$ & $\mathrm{ABL}$ & $\mathrm{ABL}$ & $\mathrm{ABL}$ \\
\hline ARG & ARG & ARG & BCR-ABL & BCR-ABL \\
\hline BCR-ABL & BCR-ABL & BCR-ABL & ALK & $\mathrm{c}-\mathrm{KIT}$ \\
\hline c-KIT & c-KIT & c-KIT & CSK & FLT3 \\
\hline PDGFR & PDGFR & PDGFR & FGR & FGFR \\
\hline DDR1 & DDR1 & SRC & LYN & RET \\
\hline \multirow[t]{23}{*}{ NQO2 } & NQO2 & YES & PKA & PDGFR \\
\hline & & FYN & CK1 & VEGFR \\
\hline & & LYN & $\mathrm{CK} 2$ & SRC \\
\hline & & HCK & SRC & \\
\hline & & LCK & RET & \\
\hline & & FGR & SYK & \\
\hline & & BLK & & \\
\hline & & FRK & & \\
\hline & & CSK & & \\
\hline & & BTK & & \\
\hline & & TEC & & \\
\hline & & BMX & & \\
\hline & & TXK & & \\
\hline & & DDR1 & & \\
\hline & & DDR2 & & \\
\hline & & ACK & & \\
\hline & & BRAF & & \\
\hline & & EGFR & & \\
\hline & & EPHA & & \\
\hline & & MAPK & & \\
\hline & & RAF & & \\
\hline & & SLK & & \\
\hline & & ZAK & & \\
\hline
\end{tabular}

$7 \%$ of patients, and fluid retention occurred in $23 \%$, most commonly as peripheral edema and pleural/pericardial effusions. Other less common side effects recorded were pancreatitis (28 patients, $6 \%$ ) and hemorrhagic events $(24 \%$ of patients, in $5 \%$ as serious event). ${ }^{27,28}$

Conclusions. Nilotinib and dasatinib tested as a second line after imatinib failure and/or intolerance have been proven to be effective and safe drugs, with the possibility of rescuing about $50 \%$ of patients with different forms of resistance. Bosutinib was proven effective not only in the second line, but also in patients resistant to previous therapy with imatinib and nilotinib and/or dasatinib. All these drugs are less or completely ineffective in patients carrying the T315I mutation. In this latter subset a third-generation inhibitor, ponatinib, was tested with brilliant results, and recently approved for patients with resistance to previous TKIs lines. This agent allowed the rescue of the majority of patients with T315I mutation with most of responses being maintained. In the last edition of 2013 ELN recommendations, allogeneic bone marrow transplant should be considered at the time of starting second line after failure of any type of TKIs, whereas it is recommended for patients after failure of two previous TKIs. 
Table 3. In vitro sensitivity of more common BCR/ABL1 kinase domain mutations.

\begin{tabular}{|c|c|c|c|c|c|}
\hline Kinase mutation & $\begin{array}{c}\text { Imatinib IC50, } \\
\text { range (nM) }\end{array}$ & $\begin{array}{l}\text { Nilotinib IC50, } \\
\text { range (nM) }\end{array}$ & $\begin{array}{c}\text { Dasatinib IC50, } \\
\text { range (nM) }\end{array}$ & $\begin{array}{c}\text { Bosutinib IC50, } \\
\text { range (nM) }\end{array}$ & $\begin{array}{c}\text { Ponatinib IC50, } \\
\text { range (nM) }\end{array}$ \\
\hline Unmutated & $260-678$ & $<10-25$ & $0,8-1,8$ & 41,6 & 0,5 \\
\hline M244V & $1,600-3,100$ & $38-39$ & 1,3 & 147,4 & 2,2 \\
\hline L248V & $1,866-10,000$ & $49,5-919$ & 9,4 & NA & NA \\
\hline G250E & $1,350->20,000$ & $48-219$ & $1,8-8,1$ & 179,2 & 4,1 \\
\hline Q252H & $734-3,120$ & $16-70$ & $3,4-5,6$ & 33,7 & 2,2 \\
\hline Y253F & $>6,400-8,953$ & $182-725$ & $6,3-11$ & 40 & 2,8 \\
\hline Y253H & $>6,400-17,700$ & $450-1,300$ & $1,3-10$ & NA & 6,2 \\
\hline E255K & $3,174-12,100$ & $118-566$ & $5,6-13$ & 394 & 14 \\
\hline E255V & $6,111-8,953$ & $430-725$ & $6,3-11$ & 230,1 & 36 \\
\hline D276G & 1,147 & 35,3 & 2,6 & 25 & NA \\
\hline E279K & 1,872 & $36,5-75$ & 3 & 39,7 & NA \\
\hline V299L & $540-814$ & 23,7 & $15,8-18$ & 1,086 & NA \\
\hline F311L & $480-1,300$ & 23 & 1,3 & NA & NA \\
\hline T315I & $>6,400->20,000$ & $697->10,000$ & $137->1,000$ & 1,890 & 11 \\
\hline T315A & 125 & NA & 760 & NA & 1,6 \\
\hline F317L & $810-7,500$ & $39,2-91$ & $7,4-18$ & 100,7 & 1,1 \\
\hline F317V & 500 & 350 & NA & NA & 10 \\
\hline M351T & $880-4,900$ & $7,8-38$ & $1,1-1,6$ & 29,1 & 1,5 \\
\hline F359V & $1,400-1,825$ & $91-175$ & $2,2-2,7$ & 38,6 & 10 \\
\hline V379I & $1,000-1,630$ & 51 & 0,8 & NA & NA \\
\hline L384M & $674-2,800$ & $39-41,2$ & 4 & 19,5 & NA \\
\hline L387M & $1,000-1,100$ & 49 & 2 & NA & NA \\
\hline H396R & $1,750-5,400$ & $41-55$ & $1,3-3$ & 33,7 & NA \\
\hline H396P & $850-4,300$ & $41-43$ & $0,6-2$ & 18,1 & 1,1 \\
\hline F486S & $2,728-9,100$ & $32,8-87$ & 5,6 & 96,1 & NA \\
\hline
\end{tabular}

\section{References:}

1. Deininger MW, O'Brien SG, Guilhot F, Goldman JM, Hochhaus A, Hughes TP, Radich JP, Hatfield AK, Mone M, Filian J, Reynolds J, Gathmann I, Larson RA, Druker BJ. International randomized study of interferon vs STI571 (IRIS) 8-year follow-up: sustained survival and low risk for progression or events in patients with newly diagnosed chronic myeloid leukemia in chronic phase (CML-CP) treated with imatinib. Blood. 2009; 114: abstr 1126

2. Baccarani M, Cortes J, Pane F, Niederwieser D, Saglio G, Apperley J, Cervantes F, Deinger M, Gratwohl A, Guilhot F, Hochhaus A, Horowitz M, Hughes T, Kantarjian H, Larson R, Radich J, Simonsson B, Silver RT, Goldman J, Hehlmann R; Europena LeukemiaNet. Chronic myeloid leukemia: an update of concepts and management recommendations od European LeukemiaNet. J Clin Oncol 2009; 27: 6041-6051 http://dx.doi.org/10.1200/JCO.2009.25.0779 PMid:19884523

3. Baccarani M, Deininger MW, Rosti G, Hochhaus A, Soverini S, Apperley JF, Cervantes F, Clark RE, Cortes JE, Guilhot F, HjorthHansen H, Hughes TP, Kantarjian H, Kim DW, Larson RA, Lipton JH, Mahon FX, Martinelli G, Mayer J, Muller MC, Niederwieser D, Pane F, Radich JP, Rousselot P, Saglio G, Saußele S, Schiffer C, Silver R, Simonsson B, Steegmann JL, Goldman JM, Hehlmann $\mathrm{R}$. European LeukemiaNet recommendations for the management of chronic myeloid leukemia: 2013. Blood. 2013; 122: 872-884 http://dx.doi.org/10.1182/blood-2013-05-501569 PMid:23803709

4. Breccia M, Alimena G. Systematic review of dasatinib in chronic myeloid leukemia. Onco Target Ther 2013; 6: 257-262 http://dx.doi.org/10.2147/OTT.S35360 $\quad$ PMid:23569389 PMCid:PMC3615898

5. Hochhaus A, Kantarjian H, Baccarani M, Lipton JH, Apperley JF, Druker BJ, Facon T, Goldberg SL, Cervantes F, Niederwieser D, Silver RT, Stone RM, Hughes TP, Muller MC, Ezzedine R, Countouriotis AM, Shah NP. Dasatinib induces notable hematologic and cytogenetic responses in chronic-phase chronic myeloid leukemia after failure of imatinib therapy. Blood 2007; 109: 2303-2309 http://dx.doi.org/10.1182/blood-2006-09-047266 PMid:17138817

6. Branford S, Hochhaus A, Mueller M, Bahceci E, Ploughman L, Mukhopadhyay J, Hughes T. Analysis of molecular data and the emergence of mutations for chronic-phase chronic myelogenous leukemia (CML-CP) patients treated with dasatinib after imatinib failure. Blood 2009; 114: abstract 3282

7. Hochhaus A, Baccarani M, Deininger M, Apperley JF, Lipton JH Goldberg SL, Corm S, Shah NP, Cervantes F, Silver RT, Niederwieser D, Stone RM, Dombret H, Larson RA, Roy L, Hughes T, Müller MC, Ezzeddine R, Countouriotis AM, Kantarjian HM. Dasatinib induces durable cytogenetic responses in patients with chronic myelogenous leukemia in chronic phase with resistance or intolerance to imatinib. Leukemia 2008; 22: 12001206 http://dx.doi.org/10.1038/leu.2008.84 PMid:18401416

8. Kantarjian H, Pasquini R, Levy V, Jootar S, Holowiecki J, Hamerschlak N, Hughes T, Bleickardt E, Dejardin D, Cortes J, Shah NP. Dasatinib or high-dose imatinib for chronic-phase chronic myeloid leukemia resistant to imatinib at a dose of 400 to 600 milligrams daily: two-year follow-up of a randomized phase 2 study (START-R). Cancer 2009; 115: 4136-4147 http://dx.doi.org/10.1002/cncr.24504 PMid:19536906

9. Apperley JF, Cortes JE, Kim DW, Roy L, Roboz GJ, Rosti G, Bullorsky EO, Abruzzese E, Hochhaus A, Heim D, de Souza CA, Larson RA, Lipton JH, Khoury HJ, Kim HJ, Sillaber C, Hughes TP, Erben P, Van Tornout J, Stone RM. Dasatinib in the treatment of chronic myeloid leukemia in accelerated phase after imatinib failure: the START a trial. J Clin Oncol 2009; 27: 3472-3479 http://dx.doi.org/10.1200/JCO.2007.14.3339 PMid:19487385

10. Cortes J, Rousselot P, Kim DW, Ritchie E, Hamerschlak N, Coutre S, Hochhaus A, Guilhot F, Saglio G, Apperley J, Ottmann O, Shah N, Erben P, Branford S, Agarwal P, Gollerkeri A, Baccarani M. Dasatinib induces complete hematologic and cytogenetic responses in patients with imatinib-resistant or -intolerant chronic myeloid leukemia in blast crisis. Blood 2007; 109. 3207-3213 http://dx.doi.org/10.1182/blood-2006-09-046888 PMid:17185463

11. Ottmann O, Dombret H, Martinelli G, Simonsson B, Guilhot F, Larson RA, Rege-Cambrin G, Radich J, Hochhaus A, Apanovitch AM, Gollerkeri A, Coutre S. Dasatinib induces rapid hematologic and cytogenetic responses in adult patients with Philadelphia chromosome positive acute lymphoblastic leukemia with resistance or intolerance to imatinib: interim results of a phase 2 study. Blood 
2007; 110: 2309-2315 http://dx.doi.org/10.1182/blood-2007-02073528 PMid:17496201

12. Shah NP, Kim DW, Kantarjian HM, Rousselot P, Llacer PE, Enrico A, Vela-Ojeda J, Silver RT, Khoury HJ, Muller MC, Lambert A, Matloub Y, Hochhaus A. Potent, transient inhibition of BCR-ABL with dasatinib $100 \mathrm{mg}$ daily achieves rapid and durable cytogenetic responses and high transformation-free survival rates in chronic phase chronic myeloid leukemia patients with resistance, suboptimal response or intolerance to imatinib. Haematologica 2010; $95: 232-240$

http://dx.doi.org/10.3324/haematol.2009.011452 PMid:20139391 PMCid:PMC2817025

13. Rea D, Vellenga E, Junghan C, Baccarani M, Kantarjian H, Lofgren C, et al. Six-year follow-up of patients with imatinibresistant or imatinib-intolerant chronic-phase chronic myeloid leukemia (CP-CML) receiving dasatinib. Haematologica 2012; 97 (s1): abstract199 PMid:22419578 PMCid:PMC3487558

14. Muller MC, Cortes JE, Kim DW, Druker BJ, Erben P, Pasquini R, Branford S, Highes TP, Radich JP, Ploughman L, Mukhopadhyay $\mathrm{J}$, Hochhaus A. Dasatinib treatment of chronic-phase chronic myeloid leukemia: analysis of responses according to pre-existing BCR-ABL mutations. Blood 2009; 114: 4944-4953 http://dx.doi.org/10.1182/blood-2009-04-214221 PMid:19779040

15. Saglio G, Hochhaus A, Goh YT, Masszi T, Pasquini R, Maloisel F, ERben P, Cortes J, Paquette R, Bradley-Garelik MB, Zhu C, Dombret H. Dasatinib in imatinib-resistant or imatinib-intolerant chronic myeloid leukemia in blast phase after 2 years of follow-up in a phase 3 study: efficacy and tolerability of 140 milligrams once daily and 70 milligrams twice daily. Cancer 2010; 116: 3852-3861 http://dx.doi.org/10.1002/cncr.25123 PMid:20564086

16. Breccia M. Alimena G. Nilotinib: a second-generation tyrosine kinase inhibitor for chronic myeloid leukemia. Leuk Res 2010; 34: 129-134 http://dx.doi.org/10.1016/j.leukres.2009.08.031 PMid:19783301

17. Giles FJ, le Coutre P, Pinilla-Ibarz J, Larson RA, Gattermann N, Ottmann OG, Hochhaus A, Radich JP, Saglio G, Hughes TP, Martinelli G, Kim DW, Novick S, Gillis K, Fan X, Cortes J, Baccarani M, Kantarjian HM. Nilotinib in imatinib-resistant or imatinib-intolerant patients with chronic myeloid leukemia in chronic phase: 48-month follow-up results of a phase II study. Leukemia 2013; 27: 107-112 http://dx.doi.org/10.1038/leu.2012.181 PMid:22763385

18. Hughes T, Saglio G, Branford S, Soverini S, Kim DW, Muller MC, Martinelli G, Cortes J, Beppu L, Gottardi E, Kim D, Erben P, Shou Y, Haque A, Gallagher N, Radich J, Hochhaus A. Impact of baseline BCR-ABL mutations on response to nilotinib in patients with chronic myeloid leukemia in chronic phase. J Clin Oncol 2009; 27: 4204-4210 http://dx.doi.org/10.1200/JCO.2009.21.8230 PMid: 19652056

19. Nicolini FE, Turkina A, Shen ZX, Gallagher N, Jootar S, Powell BL, De Souza C, Zheng M, Szczudlo T, le Coutre P. Expanding nilotinib access in clinical trials (ENACT): an open-label, multicenter study of oral nilotinib in adultpatients with imatinibresistant or imatinib-intolerant Philadelphia chromosome-positive chronic myeloid leukemia in the chronic phase. Cancer 2012; 118: 118-126 http://dx.doi.org/10.1002/cncr.26249 PMid:21732337

20. Nicolini FE, Masszi T, Shen Z, Gallagher NJ, Jootar S, Powell BL, Dorlhiac-Llacer PE, Zheng M, Szczudlo T, Turkina A. Expanding nilotinib access in clinical trials (ENACT), an open-label multicenter study of oral nilotinib in adult patients with imatinibresistant or -intolerant chronic myeloid leukemia in accelerated phase or blast crisis. Leuk Lymphoma 2012; 53: $907-914$ http://dx.doi.org/10.3109/10428194.2011.627480 PMid:22023530

21. Giles FJ, Kantarjian HM, le Coutre PD, Baccarani M, Mahon FX, Blakesley RE, Gallagher NJ, Gillis K, Goldberg SL, Larson RA, Hochhaus A, Otmann OG. Nilotinib is effective in imatinibresistant or -intolerant patients with chronic myeloid leukemia in blastic phase. Leukemia 2012; 26: $959-962$ http://dx.doi.org/10.1038/leu.2011.355 PMid:22157807

22. Cortes JE, Kantarjian HM, Brummendorf TH, Kim DW, Turkina AG, Shen ZX, Pasquini R, Khoury HJ, Arkin S, Volkert A, Besson N, Abbas R, Wang J, Leip E, Gambacorti-Passerini C. Safety and efficacy of bosutinib (SKI-606) in chronic phase Philadelphia chromosome-positive chronic myeloid leukemia patients with resistance or intolerance to imatinib. Blood 2011; 118: 4567-4576 http://dx.doi.org/10.1182/blood-2011-05-355594 PMid:21865346

23. Khoury HJ, Cortes JE, Kantarjian HM, Gambacorti-Passerini C, Baccarani M, Kim DW, Zaritskey A, Countouriotis A, Besson N, Leip E, Kelly V, Brümmendorf TH. Bosutinib is active in chronic phase chronic myeloid leukemia after imatinib and dasatinib and/or nilotinib therapy failure. Blood 2012; 119: 3403-3412 http://dx.doi.org/10.1182/blood-2011-11-390120 PMid:22371878

24. Gambacorti-Passerini $\mathrm{C}$, Brummendorfer $\mathrm{T}$, Cortes $\mathrm{J}$, et al. Efficacy and safety of bosutinib for Philadelphia chromosomepositive leukemia in older versus younger patients. Haematologica 2012; 97 (s1): abstract 757

25. Gambacorti-Passerini C, Khoury HJ, Baccarani M, Kantarjian H, Chandy M, et al. Safety and efficacy of bosutinib in patients with $\mathrm{AP}$ and $\mathrm{BP} \mathrm{CML}$ and $\mathrm{Ph}+\mathrm{ALL}$ following resistance/intolerance to imatinib and other TKIS: update from study SKI-200. J Clin Oncol 2010 ASCO meeting; abstract 6509

26. Cortes JE, Kim DW, Pinilla-Ibarz J, le Coutre P, Paquette R, Chuah $C$, et al. A pivotal phase 2 trial of ponatinib in patients with chronic myeloid leukemia (CML) and Philadelphia chromosomepositive acute lymphoblastic leukemia ( $\mathrm{Ph}+\mathrm{ALL})$ resistant or intolerant to dasatinib or nilotinib, or with the T315I BCR-ABL mutation: 12-month follow-up of the PACE trial. Blood 2012; 120: abstract 163

27. Cortes JE, Kantariian H, Shah NP, Bixby D, Mauro MJ, Flinn I, O'Hare T, Hu S, Narasimhan NI, Rivera VM, Clackson T, Turner CD, Haluska FG, Druker BJ, Deininger MW, Talpaz M. Ponatinib in refractory Philadelphia chromosome-positive leukemias. N Engl J Med 2012; 367: 2075-2088 http://dx.doi.org/10.1056/NEJMoa1205127 PMCid:PMC3777383

28. Cortes JE, Kim DW, Pinilla-Ibarz J, le Coutre P, Paquette R, Chuah C, Nicolini FE, Apperley JF, Khoury HJ, Talpaz M, DiPersio J, DeAngelo DJ, Abruzzese E, Rea D, Baccarani M, Müller MC, Gambacorti-Passerini C, Wong S, Lustgarten S, Rivera VM, Clackson T, Turner CD, Haluska FG, Guilhot F, Deininger MW, Hochhaus A, Hughes T, Goldman JM, Shah NP, Kantarjian H; PACE Investigators. A phase 2 trial of ponatinib in Philadelphia chromosome-positive leukemias. N Engl J Med 2013; 369: 1783-1796 http://dx.doi.org/10.1056/NEJMoa1306494 PMid:24180494 PMCid:PMC3886799 